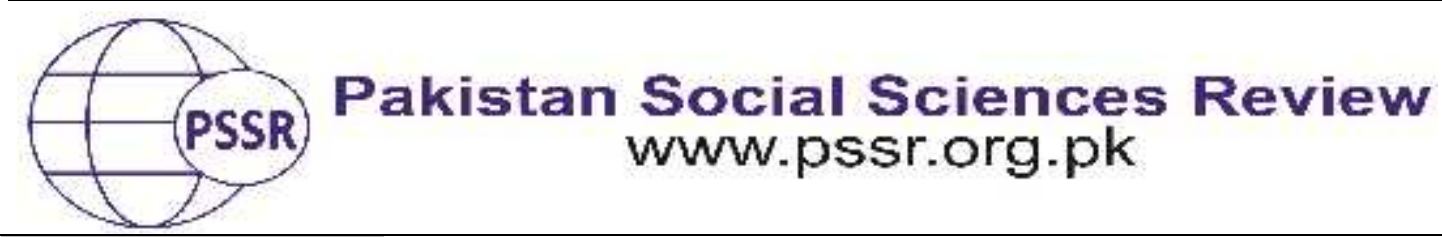

RESEARCH PAPER

\title{
Framing the Political Reality of 2014 Sit-ins: An Analysis of Mainstream English Newspapers of Pakistan
}

\author{
Abdul Rafay Khan* ${ }^{1}$ Aziz Ullah Khan ${ }^{2}$ Zubair Iqbal ${ }^{3}$
}

1. Assistant Professor of English, Government Islamia College, Civil Lines, Lahore, Lahore, Punjab, Pakistan

2. Lecturer, Department of English, University of Science and Technology Bannu, KP, Pakistan

3. M. Phil, Applied Linguistics, The University of Lahore, Punjab, Pakistan

\begin{tabular}{|c|c|}
\hline PAPER INFO & ABSTRACT \\
\hline $\begin{array}{l}\text { Received: } \\
\text { January 10, } 2021\end{array}$ & $\begin{array}{l}\text { This paper aims to study how the mainstream English } \\
\text { newspapers of Pakistan i.e. Dawn, The News, The Nation, and }\end{array}$ \\
\hline $\begin{array}{l}\text { Accepted: } \\
\text { March 01, } 2021 \\
\text { Online: } \\
\text { March 15, } 2021\end{array}$ & $\begin{array}{l}\text { The Daily Times exploited different frames to make } \\
\text { audience/readers believe in a certain way during their coverage } \\
\text { of } 2014 \text { anti-government sit-ins led by Pakistan Tehreek-e-Insaf }\end{array}$ \\
\hline $\begin{array}{l}\text { Keywords: } \\
\text { English Print } \\
\text { Media, } \\
\text { Framing, } \\
\text { Long Marches, } \\
\text { Political Reality }\end{array}$ & $\begin{array}{l}\text { (PTI) and Pakistan Awami Tehreek (PAT). Owing to the } \\
\text { remarkable role played by media in reshaping the politics of the } \\
\text { state during this movement, it becomes important to study how } \\
\text { it framed reality for its readers. The study utilizes frame } \\
\text { analysis method which focuses on different frames which are } \\
\text { used to restrict meanings for constructing a particular }\end{array}$ \\
\hline $\begin{array}{l}\text { *Corresponding } \\
\text { Author } \\
\text { abdurrafay.uos@ } \\
\text { gmail.com }\end{array}$ & $\begin{array}{l}\text { pretation in mind of the reader. The analysis of the data } \\
\text { cted majorly from headlines of the four newspapers show } \\
\text { in most of the cases the frames were selected which could } \\
\text { uce a little anger against the government; hence they } \\
\text { ributed a little in mobilizing people during the sit-ins. }\end{array}$ \\
\hline
\end{tabular}

\section{Introduction}

In a world full of political upheavals, Pakistan witnesses an unpredictable political climate which is usually very difficult to forecast. Driven by internal and external stimuli, the political stake-holders of the country have become very habitual of political adventures during a course of more than 70 years political history. Whenever a cloud of change roars, all power centers, involved the power game, play their significant roles determined by their own interests and agendas. The role of media, as one of the most powerful centers of power, has been increased in power politics since it has been freed by General Musharaf. This newly enfranchised media has accumulated more power of being key arbitrator in the history making political adventures of the state than ever before in past. 
Pakistan's mainstream English newspapers played a remarkable role in fabricating the political reality in the country and making people look at a restricted version of reality by utilizing popular frames that emerged from the situation of Anit- government sit-inns of Pakistan Tehreek-e-insaf (PTI), and Pakistan Awami Tehreek (PAT), in August 2014. Motivated by different factors but sharing the common goal of removing the then sitting Prime Minister-Nawaz Shrif, the two parties launched different marches with different names-Azadi March(PTI) and Inqilab March-which had to culminate in one big show in the capital city. PTI was motivated by the alleged rigging in the 2013 general elections; while PAT was determined to take revenge of 14 or more killings at Minhaj Trust, Lahore- a political cum religious headquarter of Dr. Tahir-ul-Qadri. The slogans raised by two political leaders-Imran Khan and Dr. Qadri showed that the long march movement would be both a political and a social movement.

The researchers of social (and political) movements view that such movements influence public policy, political, social, and economic institutions. They are witnessed to be responsible for changing tyrannical governments or changing the laws of the state. Owing to such remarkable significance in a society, they have attracted the attention of both social movement and media researchers, and active social and political actors to study how these movements help in mobilizing masses. (Meyer, 2009; Smith, 2015)

In order to study the role of English print media during the coverage of long marches and sit-ins of PTI and PAT, this research applied Frame Analysis method which is considered very relevant method of research for the study of social and political movements apart from its significance as an important ethnographic method of research. This research focused on the frames used by the four mainstream English newspapers-Dawn, The News, The Nation, and Daily Times to construct the picture of long march and sit-in events.

\section{Literature Review}

Framing is a spin technique which is used to restrict meaning so as to convey a particular interpretation in the mind of the reader. In a text, words or phrases exist in a cognitive context i.e. a pattern of beliefs, experiences, values, or knowledge stored in mind. These words or phrases bring a particular frame in the mind of the receiver. 'Don't think of an Elephant! Know Your Values and Frame the Debate' is the title of a book written by George Lakoff (2004). Here, the word elephant stands as a symbol of Democratic Party and it stirs up the frame linked with it including all the things the Democratic Party stands for.

The term frame was coined by famous sociologist Goffman (1974) in his seminal work on Frame Analysis. By frame he meantculturally determined definitions of reality that would allow people to make sense of events and objects. He perceived reality asschemata of interpretation. Conducting frame analysis one may assume situation wherein there are multiple interpretations of reality and the task is to uncover the implicit and explicit understanding. 
Entman (1993, p.52), one of the leading scholars on framing, defined the act of framing as "to select some aspects of a perceived reality and make them more salient in a communicating text, in such a way as to promote a particular problem definition, causal interpretation, moral evaluation, and/or treatment recommendation". According to D'Angelo (2002), four players take part in framing process-the communicator, the text, the recipient, and the culture. This demarcation leads to two types of frames: the cognitive frame and the message frame. The cognitive frame is shaped in the mind of the individual and is shaped by his/her interaction with the culture. The message frame is created in the text by the communicator. Scheufele (1999) viewed that framing process could be understood as an interaction between message frame and cognitive frame (Smith, 2015, p.9).

Shaw (2013) highlighted the significance of frame analysis for social movement researchers. In his view they develop more specific use of frame analysis by turning the mere ethnographic method of research into more specific method of understanding social movements. Utilizing this method of analysis, media researchers expose the political function performed by frames in mass media. They stress on how audience are restricted to preferred conclusions by highlighting some aspects of reality while hiding the other.

Snow et al. (2004), however, perceived an extended function of framing which was not restricted to providing meaning, but it was also responsible for motivating action that had to challenge the existing power structures and the understanding of reality imposed by those power structures. Fames are thus dynamic in the sense that they have some influence on our lives as certain flow of events may force us to modify our interpretations of realities according to them (Smith, 2015, p.23). In this way framing is not a method of analysis but a tool for social or political change that may be utilized by the different actors of the power politics in either way.

When we find a link between social movement theory and framing, much of the theoretical notion of the latter is seen to be built on the works of Benford and Snow (2000). They observed that "Framing describes an active procedural phenomenon that implies agency and contention at the level of reality construction.... Thereby, the political process can be characterized as a contest between different frames regarding the right to interpret an issue or social problem" (Benford\& Snow, 2000: 614).

In relation to mobilization, Klandermans (2014) categorized audiences of any movement into three categories. These audiences range from those who have least possibility to be mobilized to those who are highly motivated. They may be labeled as non-sympathizers, sympathizers, and actives. A continuum may be drawn from left to right. The mostnon sympathizers fall at the left most position of the scale and most active fall at the right most level of the scale. So, the attitudes and actions of people allot them a specific position in terms of action mobilization scale. 
Owing a grave political and social significance, the 2014 long march and sitin activities attracted the attention of the researchers and analysts to study how these events were covered and portrayed by the media. The major reason behind this interest was the enhanced role of media. The political movements of past could not experience the role such powerful role of media, either in favor or against, because media had a limited role to play. Among the major works on the media coverage of long marches and sit-ins, Khan \&Nawaz (2015) studied the metaphors utilized by mainstream English print media for portraying the major stakeholders of the marches. Their work found that metaphors used during the coverage of long marches served more to criticize Imran Khan and Dr. Tahir-ul-Qadri than the other side i.e. the government.

Khan et al. (2016) sought to highlight how the passive structures were used by the print media to hide the agency of severe actions. They identified the cases where the English news papers kept the agency of severs actions of the government hidden by bringing passive structures for narration of such events whereby the agency was either removed from the basic clauses or it was taken to a background position. Conducted under a CDA framework, their study exposed how social injustice was maintained through a biased discourse by the media.

In some recent studies, Khan \& Khan (2018) studied how the sit-in activity was caricatured by cartoons of English print media as a funny activity. Khan, Iqbal \&Khan (2019) utilized van Dijk's (2015) ideological square to trace how keeping certain facts absent the English Print media of Pakistan tilted their discourse in favor of a certain party. Although the existing studies on the English print media's discourse on Anti-government sit-inns/marches yield significant results, yet this study criticize them for lacking a systematic i.e. step by step analysis of a the discourse. To fill this gap, this study aims to utilize 'framing' which is a more systematic approach for reaching more authentic results.

\section{Material and Methods}

This research used qualitative method for analyzing data. For the analysis of frames used by the four mainstream English newspapers the 'Collective Action Frame' model of Benford\& Snow (2000) and the concept of Three categories of the audiences of any movement as introduced by Klandermans(2014)were utilized. The collective action frame model of Benford\& Snow (2000) includes diagnostic, prognostic and motivational frames. This model can be summed up in table 1.

\begin{tabular}{ccc}
\hline & Type of Frame & Its function/role in the collective action frame \\
\hline 1. & Diagnostic Frame & Identifies a problem and puts blame on an agent \\
\hline 2. & Prognostic Frame & Identifies a solution and conveys a plan of action \\
\hline 3. & Motivational Frame & Calls for action using such vocabulary \\
\hline
\end{tabular}

Klanderman's mobilization continuum can be drawn into figure 1. On this scale the non-sympathizers are at the left side. These audiences would not be ready to associate themselves with any movement, at the middle are the sympathizers who 
have a sentiment of sympathy with the movement but are not playing their active role. At the right most level are the most active who would be taking part actively in a moment.

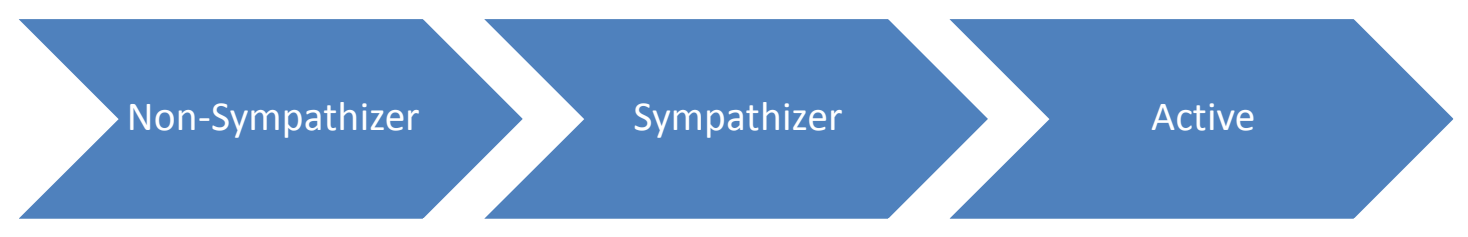

Figure 1

Utilizing both the above models, this research analyzed the top stories which appeared in print on four leading English newspapers: Dawn, The News, The Nation, and Daily Times, in their coverage of long marches of PTI and PAT. The top stories of most crucial editions of the newspapers were selected. The newspaper editions of August 14, 15 and 16 were considered most crucial as on these days the two long marches departed and reached the capital. This research focused on what type of frames were highlighted or kept hidden by the English newspapers to support either of the two sides- the government and the opposition.

\section{Results and Discussion}

During the two marches-Azadi and Inqilab- the leaders of the marching parties laid stress on the malpractices of the government which included rigging in 2013 general elections, and unjust killings of 14 or more PAT followers at Minhaj-ulQuran Trust, Lahore. These were the major issues that seemed to work behind the protest movement. There was a causal relationship between the atrocities of the government and the march activism of the two parties the Pakistan Tehreek-e-Insaf (PTI) and the Pakistan Awami Tehreek (PAT).These two major issues evoked a Diagnostic Frame in the mind of the reader who got to know why should there be a movement, against government, which should demand nothing else but the resignation of the Prime Minister.

This Diagnostic Frame (cause of the problem) evoked by the Rigging/corruption or Killing macrostructure led to the Prognostic Frame (a possible solution of the problem) which made the potential protester feel that the government is cruel and it should go now. So 'Go Nawaz Go' becomes a popular slogan serving as a Prognostic Frame, used frequently in the discourse of the leaders, for the protesters/marchers. The Diagnostic and Prognostic Frames (Consensus mobilization) suggested the followers of the groups raising slogan 'Go Nawaz Go' that Nawaz would go only if they marched on Capital to paralyze the government. So the marching on capital becomes the Motivational Frame for the marchers to legitimize their struggle against the government. Applying Klandermans' (ibid)mobilization continuum, the marching parties had to change the non- 
sympathizers into sympathizers and the sympathizers into active participants of the long march. For this purpose, they desperately needed the support of the media which serving as double edged sword had powers of moving people from left to right of the motivational continuum or right to left. It had had the frames available which could mobilize or demobilize the masses of the county for the move.

The different English print media groups presented the facts about the marches in a different way depending upon the policy of the group. Their choice of frame for portraying reality about the issue altered which showed that they had an intention of making their audience reach at different preferred interpretations of reality. The following discussion in this section would be based on analysis of the choices of frames in the four mainstream newspapers to know what interpretation of the reality these different media groups intended to produce in their audience, and how did their choices functioned for mobilization or demobilization of the masses during their coverage of the two long marches and sit-ins.

\section{Dawn}

There is no confusion about the fact that rigging/killing Frame would have serve as the diagnostic frame. If we searched for these Frames in the Dawn of August 15 and 16, the most crucial days in the history of the marching parties, when they got the highest level of attention of public and media in Pakistan, we found a very little space was given to these important frames. There might be two reasons for it. One possibility was that now it was an established fact after so many days had passed. The marching leaders had been harping on the same flute for last few months and it was taken for granted that the cause of the march lied in the malpractices of the government in 2013 general elections and in Minhaj Trust tragedy. But the important point was that it was the time when the two leaders were emphasizing on these issues with more powerful rhetoric. And in order to motivate their protesters they were in desperate need of support from media which was being lavishly provided to them by the most of the private electronic media of Pakistan. Imran Khan, spending most of his time in speaking to his followers in particular and to the masses of the country in general through his speeches, was frequently using the rigging frame. On the other hand, Dr. Qadri was concentrating on Killing of his followers. On the very day the marches entered the capital city the Dawn did not highlight the two core issues as they were being stressed upon by the leaders.

In the leading paragraph of the Dawn of August 15, 2014 we found Imran Khan saying, "Democracy and Autocracy will fight it out in Islamabad to determine the destiny of new Pakistan" (p.1). The very word autocracy evokes the whole frame of atrocities in the mind of the reader as autocracy is a form of government in which the power is saturated in the hands of an individual. However, this one line was not enough to motivate the public. If we analyze the whole coverage of the event there is no other evidence of a single phrase which might instigate the reader to action.

Another important aspect to note in this concern was that Dawn did not include Killing frame in its top stories of the two days' coverage. It gave more 
importance to PTI's leadership. We found no clue of government's malpractice at Minhaj Trust highlighted by the newspaper at the top position. So the two parties were not treated equally and were not being given equal space in the coverage causing a social injustice. In order to highlight the cause of an unyielding and strong movement against the government, the marching leaders coined a frame labeled as 'Gullu Butt' to increase the temperature of the situation and to lead to public to action mobilization after consensus mobilization. The speeches of the leaders were full of references to this frame, but the daily Dawn did not gave proper space; therefore, they constructed their message frame in such a way to influence the individual cognitive frame of their readers in such a way as could that it had a mild image of the government against which the movement was being launched. The frames highlighted by Dawn did a very little to motivate the readers for taking action to be a part of the long march mobilization, and its frame structures might procure a little support for the protagonists of social and political change in the country.

\section{The News}

The leading paragraph of the headline of The News of August 15,2014 reads, "Vowing to steering the nation out of slavery for good, Pakistan Tehreek-e-Insaf chairman Imran Khan on Thursday asserted that he would only return after Nawaz Sharif resigns as the Prime Minsiter.....I will sacrifice my life but will not let anyone enslave you." (The News, August 15, 2014).The word 'slavery' evokes the whole frame of malpractices of the government. This lexical choice occurs twice (slavery, enslave) in the above quoted lines. It implies that the cruel government has enslaved people (Diagnostic Frame) and there is a need of some savior (Prognostic Frame). "I will sacrifice my life but will not let anyone enslave you" is the motivational frame as this statement evoked the need of sacrifice and urged the people to move for sacrifice for the sake of freedom.

The top story further includes a reference to Gullu Butt (an assailant of Minhaj trust). As it further reads, "Imran persists with his demands for resignation of Nawaz ECP officials, warns Gullu Butts of Arrest......." Gullu Butts here did not refer to a person who attacked Minhaj Trust in connivance with Punjab Police, but it performed the function of Diagnostic Frame which painted a complete picture of atrocities on the minds of the readers. This Frame was missing in the coverage of the same situation by Dawn news. So, in this way The News gave more space to the real sentiments of Imran Khan and his followers as compared to Dawn newspaper.

The mentioning of Gullu Butt (diagnostic frame) and his arrest (prognostic frame), and sacrifice of the life until the nation remained slave (motivational frame) by The Newsgroup provided a space to the marching parties leadership to motivate the masses. If compared with Dawn, the frames highlighted by The News could serve more to mobilize the masses. Although the latter did not spare top position for reporting of the cause of Dr. Qadri as compared to Imran, yet it highlighted the Gull 
Butt frame which could satisfy the followers of PAT without their mentioning on the top position.

\section{The Nation}

The Analysis of Frames preferred by The Nation revealed that it was more inclined towards government. It has been discussed that the most important Frame to arouse sympathy in the readers for the long march event was the unconstitutional and unlawful killing of PAT followers at Minhaj. The Gullu Butt Frame was completely eliminated from the coverage of The Nation of August 15, and August 16.The discourse of top stories of the newspaper appeared to hide, sideline or moderate the atrocities Frame.

The newspaper mentioned Dr. Qadri's demands in 9-12th paragraph of the headline story. These paragraphs read:

"Qadri has said he plans to force out Sharif and his government by the end of this month. "There will be a sit-in. They will stay there until their demands are met and Sharif steps down," Qadri told Reuters.

The cleric's calls for revolution are appealing to poor struggling with high unemployment, daily power cuts and inflation. So are the promises he make.

"Every homeless person will be provided housing; every unemployed person will be given a job; low paid people will be provided with daily necessities," Qadri said on Thursday.

One of his main complaints is that violence against his supporters by police is not being investigated. About 2,000 of his supporters have been arrested, police say."

The above quoted chunk of discourse contains Dr. Qadri's demands. The most important demand of Dr Qadri which gave legitimacy to his march on Capital was filing of an FIR and a probe into the tragedy of Minhaj Trust keeping the high officials of the government including PM, CM of Punjab, Law minister of Punjab and a long list of others under investigation. The famous Frame used by media and the two leaders to evoke the whole maltreatment was Gullu Butt Frame, but the above mentioned data completely ignored such an important issue and mentioned those demands of Dr. Qadri which were not a grave concern at such a crucial time. The demands of jobs for unemployed, houses for homeless and daily necessities could not be popular slogans to move people, watching all this on their TV's in their bedrooms, to the roads. The collective action frames which included demands for employment for unemployed and homes for the homeless had lost their power to move people to protest as they have been betrayed many times by the political leaders in their history. The Nation's coverage did not evoke the popular/required Frame to motivate public, and its reporting could do little to motivate the public to action. 


\section{Daily Times}

Daily Times' edition of August 15 reported the long march event in almost the same way as it was reported by The Nation. The reporter of the headline story, which occupied the half front page, did not give a top position to the diagnostic frames which had to mobilize the protesters. The initial paragraphs and the headline laid stress on those macrostructures which portrayed march as a threat to political stability and civilian rule in the country. The fragments like 'causes huge traffic jams' and 'Qadri plans to occupy Jinnah Avenue' appeared on the leading positions, and their top positioning signified that the newspaper reporting was critical of Long march activism.

\section{Conclusion}

The analysis of the data collected from the most crucial days of the long march event-the days of its departure for and arrival at the capital-revealed that the English print media highlighted the frames, in most of the case, which could serve little or no purpose in mobilizing their readers to take active part in the long march event for removing an allegedly corrupt and tyrannical government. Among the four newspapers selected, only The News highlighted the frames utilized by the marching leaders for action mobilization. The rest of the three papers- Dawn, The News, and Daily Times either sidelined the major diagnostic frames which were necessary for mass mobilization, or replaced them with those which could not move people to action. The media even missed these frames while they reported the speeches of the marching leaders. A particular instance can be found in the case of 'Gullu Butt' frame. Imran Khan and Dr. Qadri were using it as a frame to evoke the sentiment of pity and fear for the catharsis of the Model Town tragedy, but either missed this important diagnostic frame altogether or sidelined it by keeping it away from the top position. Most of the English print media went straightaway to highlight the prognostic frames which could do nothing in the set of collective action frames without the diagnostic frame that was inevitably necessary for providing legitimacy to the cause of a movement. 


\section{References}

Benford, R. D. \& Snow, D. A. (2000). Framing processes and social movements: An overview and assessment. Annual Review of Sociology, 26, 611-639.

D'Angelo, P. (2002). News framing as a multi-paradigmatic research program: A response to Entman. Journal of Communication, 52(4), 870-888. http://doi.org/10.1111/j.1460-2466.2002.tb02578.x

Entman, R. M. (1993). Framing: Toward clarification of a fractured paradigm. Journal of Communication, 43(4), 51-58.

Goffman, E. (1974). Frame analysis: an essay on the organization of experience. New York: Harper \& Row.

Headline Story. (2014, August 15). Daily Times [Lahore], p. 1.

Headline Story. (2014, August 15). The Nation [Lahore], p . 1.

Headline Story. (2014, August 15). The News [Lahore], p. 1.

Khan, A.R. Iqbal, Z. Khan, A. (2019). Hiding 'Their' Positives and 'Our' Negatives: An Analysis of English Print Media's Coverage of 2014 Islamabad Sit-ins. Balochistan Journal of Linguistics, 7, 1-13.

Khan,A.R. \&Nawaz, S. (2015). Metaphors at work in media discourse: A Case of August 2014 Islamabadsit-ins. European Journal of Research and Reflection in Arts and Humanities, 3(3), 48-54.

Khan,A.R. Amin,R.U. Alam,M.F. \& Shah,S.R. (2016).Hiding agency of severe actions in English print Media: A critical discourse analysis of 2014 Islamabad sitins. Science International, 28(4), 763-766.

Klandermans, B. (2014). Framing collective action. In K. Fahlenbrach, E. Sivertsen, \& R. Werenskjold (Eds.), Media and Revolt: Strategies and Performances from the 1960s to the Present (pp. 41-58). New York, NY: Berghahn Books.

Lakoff, G. (2004). Don't Think of an Elephant Know your Values and Frame the Debate. Vermont: Chelsea: Green Publishing.

Malik, M. (2014, August 15). PTI kicks off azadi march. Dawn [Lahore], p. 1.

Meyer, D. S. (2009). How social movements matter. In J. Goodwin \& J. Jasper (Eds.), The social movements reader: Cases and concepts (2nd ed. pp. 417-422). Chichester, UK: Wiley-Blackwell.

Scheufele, D. (1999). Framing as a theory of media effects. Journal of Communication, 49(1), 103-122. http:// doi.org/10.1111/j.1460-2466.1999.tb02784.x 
Shaw, E. (2013). Frame Analysis. Encyclopædia Britannica. Encyclopædia Britannica, inc. https://www.britannica.com/topic/frame-analysis

Smith, R. L. (2015). Inspiring Action: Measuring the Effect of Motivational Frames on Social Movement Mobilization. Dissertations and Theses. Paper 2510. Portland State University.

Snow, D. A. Soule, S. A. \&Kriesi, H. (Eds.). (2004). The Blackwell Companion to Social Movements. Malden, MA: Blackwell Publications. 